Article

\title{
The Sesquiterpenes $\beta$-Caryophyllene and Caryophyllene Oxide Isolated from Senecio salignus Act as Phytogrowth and Photosynthesis Inhibitors
}

\author{
B. Arturo Sánchez-Muñoz ${ }^{1}$, Maria Isabel Aguilar ${ }^{2}$, Beatriz King-Díaz ${ }^{1}$, José Fausto Rivero ${ }^{2}$ \\ and Blas Lotina-Hennsen ${ }^{1, *}$
}

1 Departamento de Bioquímica, Facultad de Química, Universidad Nacional Autónoma de México, Ciudad Universitaria, Delegación Coyoacan, México D. F. 04510, Mexico

2 Departamento de Farmacia, Facultad de Química, Universidad Nacional Autónoma de México, Ciudad Universitaria, Delegación Coyoacan, México D. F. 04510, Mexico

* Author to whom correspondence should be addressed; E-Mail: blas@unam.mx;

Tel.: +55-5622-5294.

Received: 9 December 2011; in revised form: 26 January 2012 / Accepted: 1 February 2012 /

Published: 6 February 2012

\begin{abstract}
The $n$-hexane extract of $S$. salignus plants inhibited ATP synthesis and two sesquiterpenes, the $\beta$-caryophyllene (1) and caryophyllene oxide (2) were isolated from this nonpolar fraction. Compound 1 inhibited by $42 \%$ the root elongation of Physalis ixocarpa seedlings at $50 \mu \mathrm{g} / \mathrm{mL}$ and by $53 \%$ at $150 \mu \mathrm{g} / \mathrm{mL}$, whereas at $150 \mu \mathrm{g} / \mathrm{mL}$ this compound only inhibited root elongation of Echinochloa crus-galli by $30 \%$. On the other hand, compound 2 had no effect on either germination or root and stem growth of E. cruss galli and P. ixocarpa. However, $\mathbf{1}$ and $\mathbf{2}$ inhibited the dry biomass of $P$. ixocarpa plants grown for 18 days previous to treatment and it was found that $\mathbf{1}$ was the most active biomass inhibitor. The Chl $a$ fluorescence transient in vivo experiment indicates that 1 $(100 \mu \mathrm{g} / \mathrm{mL})$ has a major effect at $72 \mathrm{~h}$ after treatment on leaves of $P$. ixocarpa plants by inhibiting photosystem II (PS II) transforming active reaction centers to "heat sinks" or the formation of silent reaction centers unable to reduce $\mathrm{Q}_{\mathrm{A}}$. $\beta$-Caryophyllene also induces chlorosis on treated leaves.
\end{abstract}

Keywords: Senecio salignus; $\beta$-caryophyllene; caryophyllene oxide; phytogrowth inhibitor; photosynthesis; Chlorophyll $a$ fluorescence 


\section{Introduction}

The genus Senecio includes approximately 1,500 species widely distributed in Mexico and Central America [1]. Among the many species, the synonymous genus Barkleyanthus only has a single species: B. salicifolius or Senecio salignus (H.B.K.) Rob. and Brett. Quercetin was isolated from S. salignus (B. salicifolius) [2]. Furoeremophilane epoxides were also isolated from the aerial parts of S. salignus and 7-ketofuranoeremophilane from the roots in 1976 [3]. Later, the same authors found the pyrrolizidine alkaloid 7-angelylheliotridine [4]. S. salignus leaves are used against intermittent fever and rheumatism [5]. Our search for secondary metabolites in plants that affect photosynthesis, identified two sesquiterpenes: $\beta$-caryophyllene (1) and caryophyllene oxide (2) in S. salignus. It is well known that $\beta$-caryophyllene has anti-inflammatory, insecticidal and fungicidal [6] activities. In this work, compound 1 inhibited the germination and growth of Physalis ixocarpa, as well as the growth (root and stem elongation) of Echinocloa crus-galli. In vitro assays showed that sesquiterpene $\mathbf{1}$ also inhibited photosynthetic activities; however, compound $\mathbf{2}$ only inhibited Physalis ixocarpa plant growth, root and stem elongation. Light reactions of photosynthesis were performed by fluorescence induction curves of chlorophyll $a$ of photosystem II (PS II), as shown by a JIP test.

\section{Results and Discussion}

\subsection{Sesquiterpene Isolation and ATP Synthesis Determination}

In the screening bioassay (ATP synthesis) it was found that the $n$-hexane extract (leaves and stems) of $S$. salignus, exhibited the major inhibition result $\left(\mathrm{I}_{50} 79.3 \mu \mathrm{g} / \mathrm{mL}\right.$ ) (Figure 1), indicating that it might contain secondary metabolites with inhibitory activity on photosynthesis.

Figure 1. Inhibitory effect of increasing concentrations of $n$-hexane extract (obtained from aerial parts of $S$. salignus) on ATP synthesis rate of spinach thylakoids. Control value was $971 \mu \mathrm{M}$ ATP $/ \mathrm{mg} \mathrm{Chl} \times \mathrm{h}$. The data are results of three replicates.

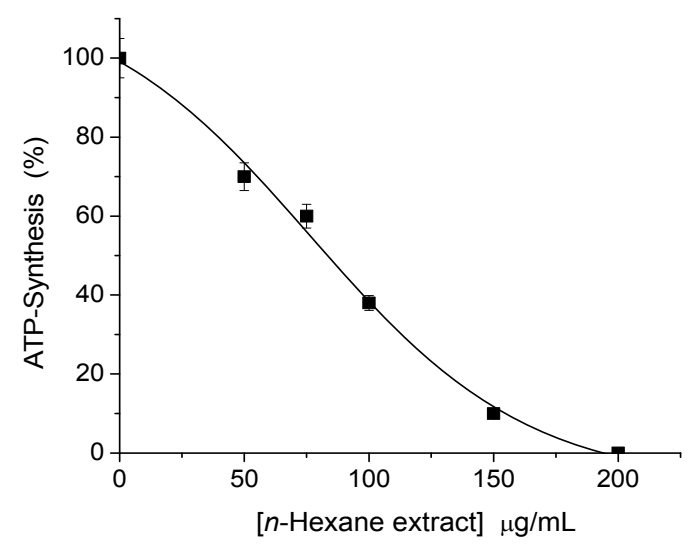

F30-F54 of the primary fraction obtained from a chromatographic column inhibited ATP synthesis with an $\mathrm{I}_{50}$ value equal to that obtained for the extract. In order to know the compounds involved in this active fraction, a secondary chromatographic fractionation eluting with an ascendant gradient of $n$-hexane-EtOAc 80:20, and then with acetone 100\%, gave a mixture of compounds, spectroscopically identified as $\beta$-caryophyllene (1, $3 \mathrm{mg}$ ) and caryophyllene oxide (2, $2 \mathrm{mg}$ ) [7] (Figure 2). 
Figure 2. Structures of $\beta$-caryophyllene (1), and caryophyllene oxide (2).

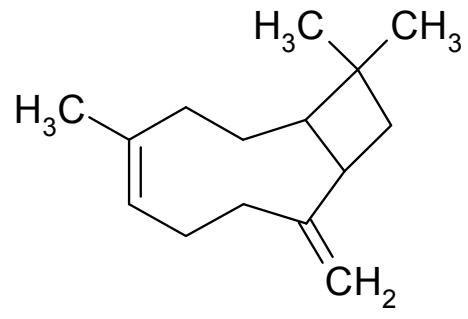

(1)

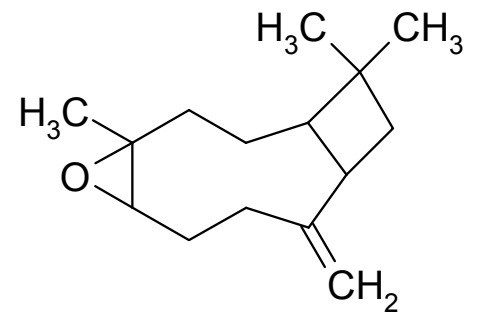

(2)

2.2. Effects of $\mathbf{1}$ and $\mathbf{2}$ on Germination and Root and Stem Growth of E. cruss-galli and P. ixocarpa

As concentration of caryophyllene oxide increased root elongation of E. crus-galli was partially inhibited (23 and $30 \%$ at 100 and $150 \mu \mathrm{g} / \mathrm{mL}$ respectively); the significance values were 0.014 and $1.21 \times 10^{-4}$ (obtained from the statistical $t$ test for two populations method). The root growth of $P$. ixocarpa plants was inhibited by 42 to $53 \%$, when concentrations of 1 were varied from 50 to $150 \mu \mathrm{g} / \mathrm{mL}$ with $p$ values of 0.0046 and $1.94 \times 10^{-4}$ (Table 1 ). These results are in agreement with the previously reported inhibition of seed germination, root and shoot growth of Brassica. campestris, Raphanus sativus, Lactuca sativa, Mikania micrantha and Achyranthes japonica [8]. On the other hand, compound $\mathbf{2}$ had no effect on either germination and root and stem growth of E. cruss-galli and P. ixocarpa.

Table 1. $\beta$-Caryophyllene inhibition of root, shoot and germination of $P$. ixocarpa seedlings.

\begin{tabular}{lccccc}
\hline $\begin{array}{l}\text { Conc. } \\
{[\boldsymbol{\mu g} / \mathbf{m L}]}\end{array}$ & $\begin{array}{c}\text { Root Elongation } \\
(\%) \boldsymbol{p}\end{array}$ & $\begin{array}{c}\text { Shoot Elongation } \\
(\mathbf{\%}) \boldsymbol{p}\end{array}$ & $\begin{array}{c}\text { Germination } \\
(\mathbf{\%})\end{array}$ \\
\hline 50 & 42 & 0.0046 & 16 & 0.075 & 0 \\
100 & 44 & $6.04 \times 10^{-4}$ & 18 & 0.06 & 0 \\
150 & 53 & $1.94 \times 10^{-4}$ & 19 & 0.064 & 4 \\
\hline
\end{tabular}

\subsection{Postemergence Activity of $\mathbf{1}$ and $\mathbf{2}$ on Biomass Production of P. ixocarpa and L. perenne Plants}

Compounds 1 and 2 acted inhibiting mainly the dry biomass production of $P$. ixocarpa plants (Table 2). Compound $\mathbf{1}(100 \mu \mathrm{M})$ inhibited the dry biomass of $P$. ixocarpa plants by $37 \%$, and $\mathbf{2}$ only by $22 \%$, suggesting that the double bond between carbons $4-5$ in the $\beta$-caryophyllene molecule is necessary for activity. L. perenne plants were less inhibited by both sesquiterpenes. Figure $3 \mathrm{~A}$ shows bleached leaves of $P$. ixocarpa plants treated with $\mathbf{1}$, after one week and the elongation of the plant decreased (Figure 3B), which are in agreement with the dry biomass and bleaching effect results reported for monoterpene derivatives of another Asteraceae species plant family [9] which inhibits phytoene desaturase, a key enzyme in carotenoid pigment biosynthesis. Since carotenoids protect chlorophyll from photooxidation, their lack would result in loss of chlorophyll. The bleaching of $P$. ixocarpa leaves caused by $\beta$-caryophyllene suggests that it could act as a carotenoid biosynthesis inhibitor. L. perenne plants were less inhibited (15\% and 4\%) with 1 and $2(100 \mu \mathrm{g} / \mathrm{mL})$. 
Table 2. Effects of $\mathbf{1}$ and $\mathbf{2}$ on biomass production in vivo (measured as dry weight of P. ixocarpa and L. perenne plants grown previously for 18 days before treatment). The data are results of five replicates.

\begin{tabular}{lcccc}
\hline & \multicolumn{2}{c}{$\boldsymbol{P . \text { ixocarpa }}$} & \multicolumn{2}{c}{ L. perenne } \\
\hline Comp / Conc. & $\mathbf{G}$ & $\mathbf{\%}$ & $\mathbf{g}$ & \% \\
\hline Control & $0.7203 \pm 0.184$ & 100 & $1.068 \pm 0.031$ & 100 \\
\hline $\mathrm{DCMU}$ & $0.533 \pm 0.053$ & 74 & $0.897 \pm 0.054$ & 84 \\
\hline $\mathbf{1}) /[\mu \mathrm{g} / \mathrm{mL}]$ & & & & \\
25 & $0.663 \pm 0.03$ & 92 & $1.107 \pm 0.142$ & 104 \\
50 & $0.575 \pm 0.021$ & 80 & $0.879 \pm 0.132$ & 82 \\
100 & $0.45 \pm 0.104$ & 63 & $0.908 \pm 0.197$ & 85 \\
\hline$(\mathbf{2}) /[\mu \mathrm{g} / \mathrm{mL}]$ & & & & \\
25 & $0.685 \pm 0.055$ & 95 & $0.953 \pm 0.111$ & 89 \\
50 & $0.654 \pm 0.065$ & 91 & $0.962 \pm 0.117$ & 90 \\
100 & $0.657 \pm 0.02$ & 78 & $1.02 \pm 0.111$ & 96 \\
\hline
\end{tabular}

Figure 3. (A) Bleaching of the $P$. ixocarpa leaves observed on plants after one week treated with: (1) Control; (2) $50 \mu \mathrm{M} \mathrm{DCMU;} \mathrm{(3)} 50$ and (4) $100 \mu \mathrm{g} / \mathrm{mL}$ of $\beta$-caryophyllene. (B) shows the plants growth under the effect of: (1) control; (2) control with the solvent (EtOH); (3) 50 and (4) $100 \mu \mathrm{g} / \mathrm{mL}$ of $\beta$-caryophyllene and (5) $50 \mu \mathrm{M}$ DCMU.

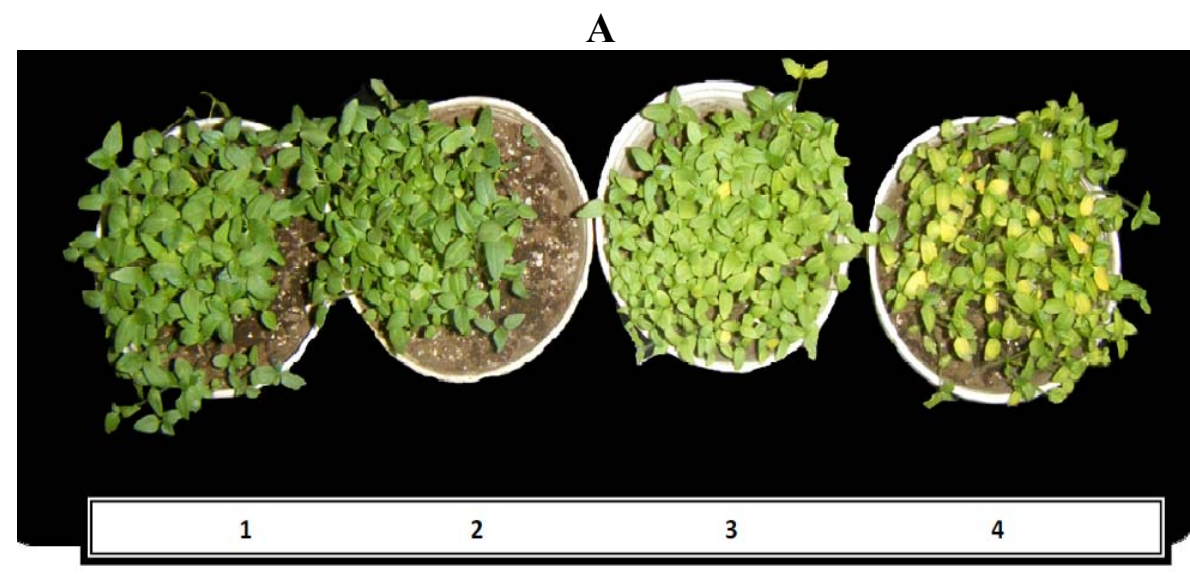

B

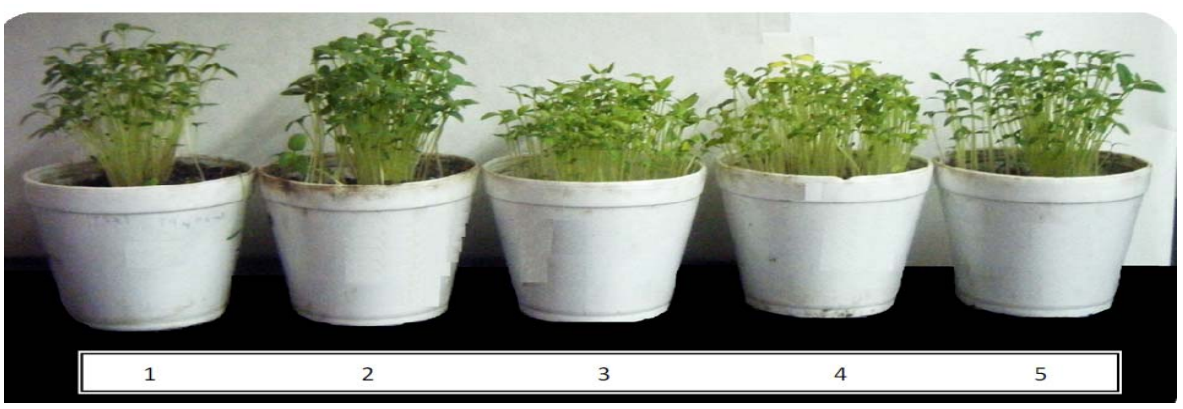




\subsection{Localization of the Target of 1 on Photosynthetic Electron Transport Chain Studied by the} Fluorescence of Chl a in Vivo Technique on Leaves of P. ixocarpa and L. perenne Plants

Chlorophyll $a$ fluorescence is an intrinsic evidence of the photosynthetic system and the intensity of the fluorescence is a direct measure of the PS II activity. The fluorescence induction curve of intact leaves of $P$. ixocarpa and L. perenne plants, exhibited a polyphasic rise O-J-I-P transient (control leaves) (Figure 4) [10]. The addition of the herbicide DCMU, used as positive control, resulted in a fast rise of fluorescence yield during the first $2 \mathrm{~ms}$ of illumination, transforming the regular O-J-I-P sequence into an O-J curve (Figure 4) [10]. The plot on a logarithmic time scale revealed that there are large differences between the control and samples treated with $100 \mu \mathrm{M}$ of $1,72 \mathrm{~h}$ after treatments (Figure 4).

Figure 4. Fluorescence rise kinetic curves of $P$. ixocarpa leaves measured $72 \mathrm{~h}$ after treatment with $\mathbf{1}, 100 \mu \mathrm{g} / \mathrm{mL}(\mathbf{\Delta})$, control (ם) and $50 \mu \mathrm{M} \operatorname{DCMU}(\bigcirc)$. Data are an average of ten replicates.

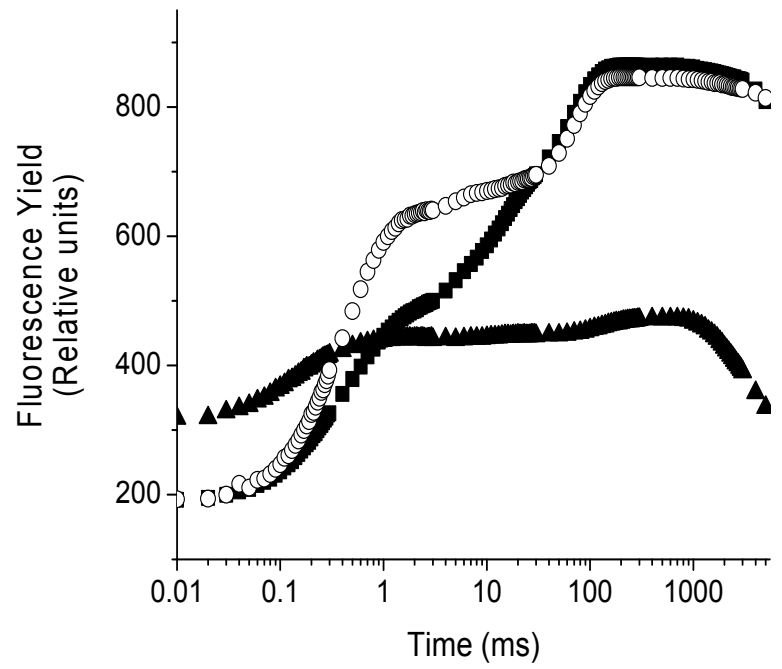

From the kinetics data of the fluorescence curve measured at 24, 48 and $72 \mathrm{~h}$ after treatment on leaves and compared with the control, various parameters were calculated and plotted as a radar graph, a circular graphic with a series of spokes or rays projecting from a central point, with each ray label representing a different variable (Figure 5). Data values were normalized to a common specific range or percentile values. Figure 5 shows the parameters (Strasser et al. [11]) of $P$. ixocarpa plants affected with 1, Panel A shows the effects at $24 \mathrm{~h}$ of treatment. Performance index decreased $25 \%$ and $10 \%$ at 50 and $100 \mu \mathrm{g} / \mathrm{mL}$, respectively; and the absorption per reaction center (ABS/RC), the quantum yield for energy dissipation $\mathrm{PHI}\left(\mathrm{D}_{0}\right)$, the trapped energy flux per reaction center $\mathrm{TR}_{0} / \mathrm{RC}$ and the indicator of the water splitting enzyme function $\left(\mathrm{dV} / \mathrm{dt}_{0}\right)$ all were increased $10 \%$ at $100 \mu \mathrm{g} / \mathrm{mL}$. Furthermore, at $72 \mathrm{~h}$ of treatments of $P$. ixocarpa plants with $1(100 \mu \mathrm{g} / \mathrm{mL})$ : The electron transport per cross section $\left(\mathrm{ET}_{0} / \mathrm{CS}\right)$ and the maximum quantum yield of primary photochemistry $\left[\mathrm{PHI}\left(\mathrm{P}_{0}\right)\right]$ decreased $50 \%$ (Figure 5, Panel C). The probability that a trapped exciton moves an electron into the electron transport chain beyond $\mathrm{Q}_{\mathrm{A}}-\left(\mathrm{PSI}_{0}\right)$, the density of the reaction centers $\left(\mathrm{RC} / \mathrm{CS}_{0}\right)$, the trapping and the electron transport per cross section $\left(\mathrm{TR}_{0} / \mathrm{CS}\right.$ and $\left.\mathrm{ET}_{0} / \mathrm{CS}\right)$ decreased around $50 \%$; while the following parameters increased up to $20 \%: \mathrm{dV} / \mathrm{dt}_{0}, \mathrm{ABS} / \mathrm{RC}$ and $\mathrm{TR}_{0} / \mathrm{RC}$. These observations suggested that 
some PSII RCs were transformed to "heat sinks" or "silent reaction centers"; these centers can neither reduce $Q_{A}$ and their excitation energy is dissipated as heat [11], this is the reason why $\mathrm{PHI}\left(\mathrm{D}_{0}\right)$ values increase. The mechanism of action of $\mathbf{1}$ is similar to other natural products like robustaflavone [12]. In panel D the effects of $50 \mu \mathrm{M}$ of DCMU on the parameters are shown to compare them.

Figure 5. Effect of 1 at $50(\boldsymbol{\square})$ and $100 \mu \mathrm{g} / \mathrm{mL}(\boldsymbol{\Delta})$ on different calculated parameters from OJIP curves measured on P. ixocarapa plants treated after $24 \mathrm{~h}$ (Panel A), $48 \mathrm{~h}$ (Panel B) and $72 \mathrm{~h}$ (Panel C), and $50 \mu \mathrm{M}$ DCMU (Panel D) after $72 \mathrm{~h}$ of treatment.

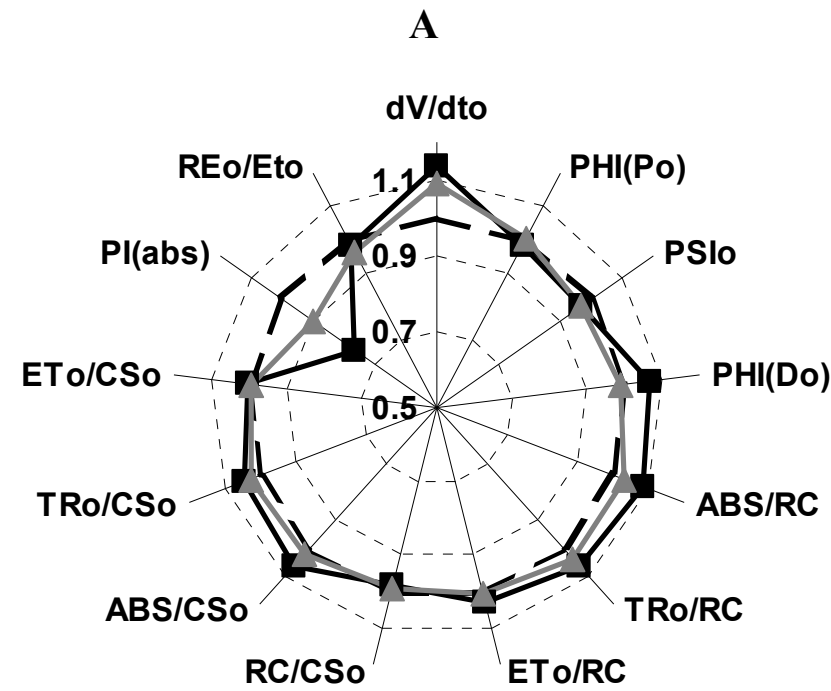

C

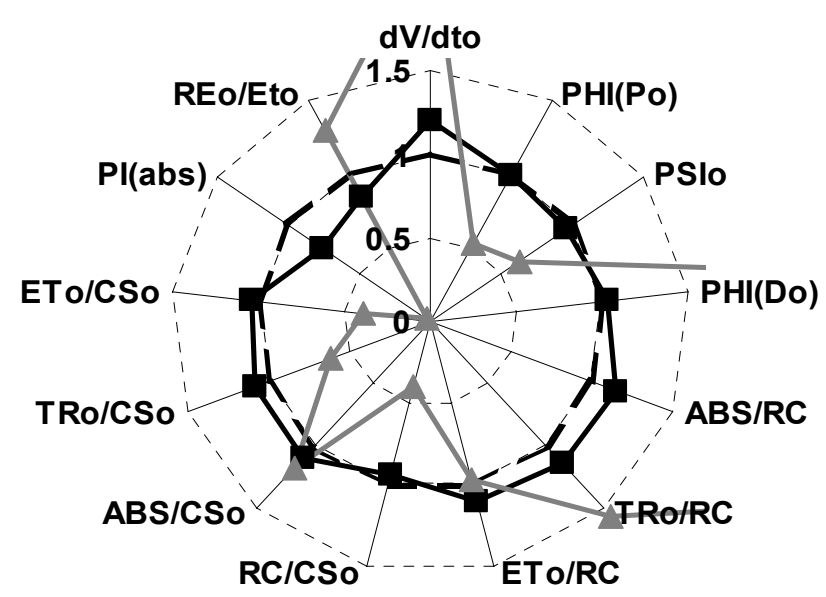

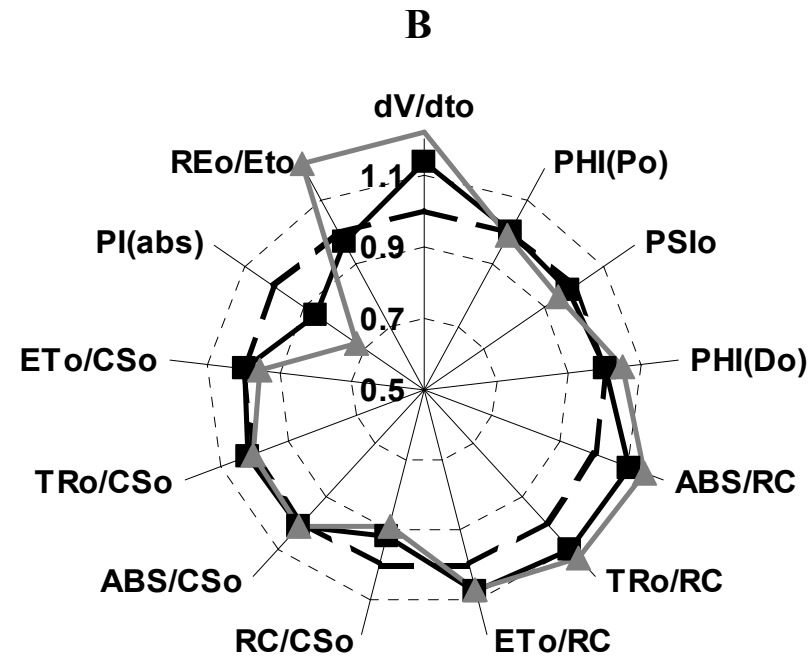

D

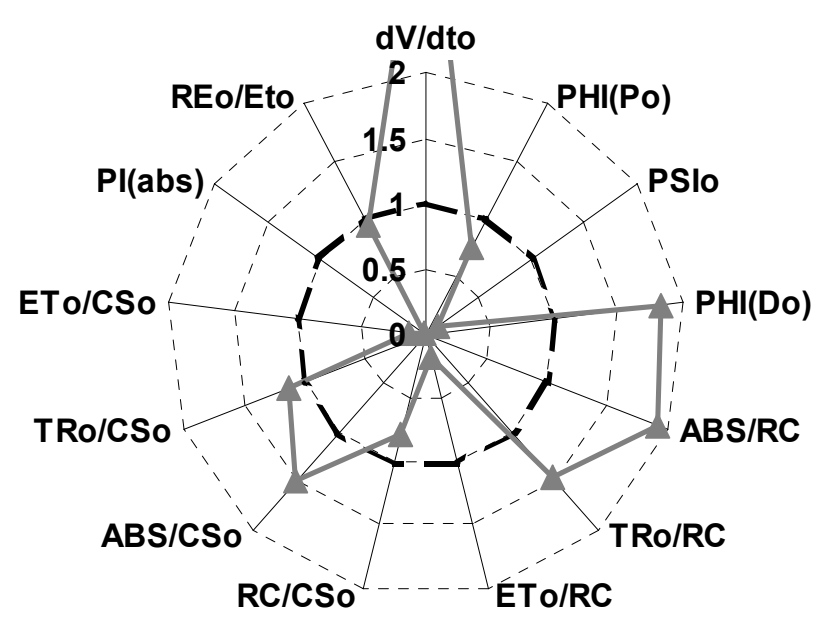

Table 3, shows how the active reaction centers $\left(\mathrm{RC}^{\mathrm{Si}}\right)$, calculated as $\left[(\mathrm{ABS} / \mathrm{RC})_{\mathrm{C}} /(\mathrm{ABS} / \mathrm{RC})_{\mathrm{T}} \times 100\right]$ for each treatment; $\left[(\mathrm{ABS} / \mathrm{RC})_{\mathrm{C}}\right.$ means for control value and the $(\mathrm{ABS} / \mathrm{RC})_{\mathrm{T}}$ means the treatments values] decreased in function of time of treatment. Thus $1(100 \mu \mathrm{M})$ at $72 \mathrm{~h}$ of treatment decreased $86 \%$, and the increased value of the $\mathrm{RE} / \mathrm{ET}_{0}$ parameter is due to the lack of the reduced equivalents of PS II (Figure 5, Panels B and C). 
Table 3. Active Reaction Centers calculated as $\left[(\mathrm{ABS} / \mathrm{RC})_{\mathrm{C}} / \mathrm{ABS} /(\mathrm{RC})_{\mathrm{T}}\right] \times 100$ in control and treated $P$. ixocarpa plants with $\beta$-caryophyllene 50 and $100 \mathrm{mg} / \mathrm{mL}$.

\begin{tabular}{ccccccc}
\hline & \multicolumn{2}{c}{$\mathbf{2 4} \mathbf{h}$} & \multicolumn{2}{c}{$\mathbf{4 8} \mathbf{~}$} & \multicolumn{2}{c}{$\mathbf{7 2} \mathbf{~}$} \\
\hline $\begin{array}{c}\mathbf{( 1 )} \\
{[\boldsymbol{\mu} \mathbf{g} / \mathbf{m L}]}\end{array}$ & $\mathbf{A B S} / \mathbf{R C}$ & $\frac{\text { Active RC }}{\mathbf{( \% )}}$ & \multirow{2}{*}{ ABS/RC } & $\frac{\text { Active RC }}{\mathbf{( \% )}}$ & \multirow{2}{*}{ ABS/RC } & $\frac{1}{\text { Active RC }}$ \\
\hline 0 & $1.91 \pm 0.19$ & 100 & $2.053 \pm 0.25$ & 100 & $2.282 \pm 0.27$ & 100 \\
25 & $1.736 \pm 0.11$ & 110 & $1.992 \pm 0.14$ & 103 & $1.888 \pm 0.08$ & 120 \\
50 & $2.09 \pm 0.22$ & 91 & $2.273 \pm 0.13$ & 90 & $2.66 \pm 0.5$ & 86 \\
100 & $1.98 \pm .25$ & 96 & $3.323 \pm 1.49$ & 62 & $16.13 \pm 3.4$ & 14 \\
\hline
\end{tabular}

\section{Experimental}

\subsection{General}

\subsubsection{Reagents}

Reagents were purchased from Sigma-Aldrich and the salts from J. T. Baker.

\subsubsection{Methods}

\subsubsection{Tested Material}

Aerial parts of $S$. salignus were collected in the state of Guerrero, Mexico in 2004 (R. Santiago, collection No R1995) and a voucher specimen was deposited at Facultad de Ciencias UNAM. No 115634 . The aerial parts of S. salignus were dried, powdered and extracted exhaustively by maceration at room temperature with $n$-hexane. The resultant crude extract $(22 \mathrm{~g})$ inhibited ATP synthesis $\left(\mathrm{I}_{50}=79.3 \mu \mathrm{g} / \mathrm{mL}\right.$ ) (Figure 1) and was fractionated via column chromatography on silica gel $(0.0063-0.200 \mathrm{~mm})$, and eluted with a mixture of increasing polarity gradient of $n$-hexane-EtOAc. The fractions eluted with $n$-hexane-EtOAc 90:10 were subjected to a second fractionation and eluted with mixtures of $n$-hexane-EtOAc of ascendant polarity, and $\beta$-caryophyllene and caryophyllene oxide were isolated with hexane-EtOAc 80:20 (Figure 2). The compounds structures were identified by spectroscopic methods with a Bruker DRX 400spectrometer for NMR, for mass spectra an Shimadzu QP5050A device for electron impact $(70 \mathrm{eV})$ low-resolution (EI-MS) was used and for gas chromatography/mass (GC/MS) spectrometry an Shimadzu QP-5050A, equipped with a PTETM_5 was used, to give values consistent with data reported in the literature [7].

\subsubsection{Chloroplast Isolation and Chlorophyll Determination}

Intact chloroplasts were isolated from market spinach leaves (Spinacea oleracea) as reported [13,14]. Chloroplasts were suspended in a small volume of the following solution: $400 \mathrm{mM}$ sucrose, $5 \mathrm{mM}$ $\mathrm{MgCl}_{2}, 10 \mathrm{mM} \mathrm{KCl}$, and $30 \mathrm{mM} \mathrm{N}$-Tris[hydroxymethyl)methyl]glycine (tricine) $\mathrm{pH} 8.0$ with $\mathrm{KOH}$ addition. Chloroplasts were stored as concentrated suspension in the dark for $1 \mathrm{~h}$ at $4{ }^{\circ} \mathrm{C}$. The chlorophyll (Chl) concentration was measured according to Strain et al. [15]. 


\subsubsection{Determination of ATP Synthesis}

Intact chloroplasts $(20 \mu \mathrm{g}$ of $\mathrm{Chl} / \mathrm{mL})$ were broken before each assay by osmotic rupture in a solution (3 mL) containing: $100 \mathrm{mM}$ sorbitol, $10 \mathrm{mM} \mathrm{KCl}, 5 \mathrm{mM} \mathrm{MgCl} 2,0.5 \mathrm{mM} \mathrm{KCN}, 1 \mathrm{mM}$ tricine- $\mathrm{KOH}$ at $\mathrm{pH} 8.0$ in the presence of $50 \mu \mathrm{M}$ methylviologen (MV) and $1 \mathrm{mM}$ adenosine diphosphate (ADP) at $\mathrm{pH}$ 6.5. The $\mathrm{pH}$ was adjusted to 8.0 with $50 \mathrm{mM} \mathrm{KOH}$ and ATP synthesis was titrimetrically determined using a microelectrode (Orion Mod. 8103 Ross) connected to a potentiometer (Corning Medical, model 12, Acton, MA, USA) with an expanded scale and a Gilson recorder (Kipp \& Zonen, Bohemia, NY, USA). Alkalization rates were measured in the linear part during illumination. The reaction was calibrated by back titration with saturated $\mathrm{HCl}$. The reaction started when turning the light on in the presence of chloroplasts $(20 \mu \mathrm{g}$ of chlorophyll per $\mathrm{mL})[14,16]$. The $\mathrm{I}_{50}$ value (concentration producing 50\% inhibition) for each activity was determined from plots of the activity at different concentrations of compound.

\subsubsection{Chlorophyll a Fluorescence of PS II}

Chlorophyll fluorescence induction curves were measured at room temperature with a Hansatech Handy PEA (Plant Efficient Analyzer) as previously described [12]. The maximum fluorescence yield of PS II was generated using three light-emitting diodes (broad $650 \mathrm{~nm}$ ). The pulse duration was $2 \mathrm{~s}$, with intensity of $2830 \mathrm{~nm}$ and gain of 0.7 . Chlorophyll fluorescence determination in vivo, in intact and dark adapted (30 $\mathrm{min}$ ) leaves, was performed for control and sprayed plants with concentrations of 25, 50 and $100 \mu \mathrm{g} / \mathrm{mL}$ of $\mathbf{1}$ and 2, after 24, 48 an $72 \mathrm{~h}$ of treatments. Data were analyzed and processed with Handy PEA and Biolyzer programs to obtain different photosynthetic parameters associated to PSII, according to the O-J-I-P test equations [14,17]: $\mathrm{F}_{0}$ is the Fluorescence intensity level at $20 \mu \mathrm{s}$ when plastoquinone electron acceptor pool $\left(\mathrm{Q}_{\mathrm{A}}\right)$ is fully oxidized; Fm is the Fluorescence level when $\mathrm{Q}_{\mathrm{A}}$ is transiently fully reduced; $\mathrm{M}_{0}$ is an indication of the water splitting enzyme function calculated as $\mathrm{dV} / \mathrm{dt}_{0}=4\left[\left(\mathrm{~F}_{300}-\mathrm{F}_{0}\right) /\left(\mathrm{F}_{\mathrm{M}}-\mathrm{F}_{0}\right)\right] ; \mathrm{ABS} / \mathrm{RC}$ is the absorption of photons flux (ABS) per active reaction center (RC) showing the antenna size equal to $\left(\mathrm{M}_{0} / \mathrm{V}_{\mathrm{J}}\right) / \mathrm{PHI}\left(\mathrm{P}_{0}\right)$; ET/RC is the electron transport rate per active reaction center calculated as $\left(\mathrm{M}_{0} / \mathrm{V}_{\mathrm{J}}\right)\left(1-\mathrm{V}_{\mathrm{J}}\right)$; TR/RC is the trapped energy flux per RC (at $\mathrm{t}=0$ ) equal to $\mathrm{M}_{0}\left(1 / \mathrm{V}_{\mathrm{J}}\right)$; $\mathrm{dR} / \mathrm{RC}$ is the efficiency when an electron moves from the reduced PSII intersystem electron acceptors to the PSI electron acceptors end calculated as $\left(1-\mathrm{V}_{\mathrm{I}} / 1-\mathrm{V}_{\mathrm{J}}\right)$; RE/RC is the reduction of the PSI electron acceptor end side per $\mathrm{RC}$ at $\mathrm{t}=0$ calculated as $(\mathrm{dR} / \mathrm{RC})(\mathrm{ET} / \mathrm{RC})$; $\mathrm{PHI}\left(\mathrm{P}_{0}\right)$ is the maximum quantum yield of primary photochemistry at $\mathrm{P}$ transient $(\mathrm{t}=0)$, it measures the PS II efficiency at plastoquinone pool reduction equal to $1-\left(\mathrm{F}_{0} / \mathrm{F}_{\mathrm{M}}\right)$; $\mathrm{PSI}_{0}$, calculated as $1-\mathrm{V}_{\mathrm{J}}$ is the probability $(a t=0)$ that a trapped exciton moves an electron into the electron transport chain beyond $\mathrm{Q}_{\mathrm{A}}{ }^{-}$; $\mathrm{PHI}\left(\mathrm{D}_{0}\right)$ is the quantum yield (at $\left.\mathrm{t}=0\right)$ of energy dissipation determined as $\left(\mathrm{F}_{\mathrm{J}}-\mathrm{F}_{0}\right) /\left(\mathrm{F}_{\mathrm{M}}-\mathrm{F}_{0}\right) ; \mathrm{V}_{\mathrm{J}}$, is the fluorescence quantum yield at $\mathrm{J}$ transient and used as an indication of PS II efficiency in the primary photochemistry; $\mathrm{V}_{\mathrm{I}}$ is the relative variable fluorescence at $30 \mathrm{~ms}$ calculated as $\left(\mathrm{F}_{30 \mathrm{~ms}}-\mathrm{F}_{0}\right) /\left(\mathrm{F}_{\mathrm{M}}-\mathrm{F}_{0}\right)$; $\mathrm{RC} / \mathrm{CS}$ determined as $\mathrm{PHI}\left(\mathrm{P}_{0}\right)\left(\mathrm{V}_{\mathrm{J}} / \mathrm{M}_{0}\right)(\mathrm{ABS} / \mathrm{CS})$, is the density of the reaction centers; $\mathrm{ABS} / \mathrm{CS}$ equal to $\mathrm{F}_{0}$, a phenomenological energy flux is the absorption flux per excited cross section; $\mathrm{RC} / \mathrm{ABS}$ is the fraction of reaction center $\mathrm{Chl}$ molecules relative to the total $\mathrm{Chl}$ content; $\mathrm{PI}(\mathrm{abs})$ is the performance index $(\mathrm{PI})$ on absorption basis calculated as $[\mathrm{RC} / \mathrm{ABS}] \times\left[\mathrm{PHI}\left(\mathrm{P}_{0}\right) /\left(1-\mathrm{PHI}\left(\mathrm{P}_{0}\right)\right] \times\left[\mathrm{PSI}_{0} /\left(1-\mathrm{PSI}_{0}\right)\right]\right.$. 


\subsubsection{Seed Germination Bioassays}

Monocot seeds of Echinochloa crus galli L. P. Beauv. an annual grass and dicotyledon seeds of Physalis ixocarpa L. (green tomato) were purchased from Semillas Berentsen, S. A. de C. V. (Celaya, Guanajuato, Mexico). Germination tests were run in triplicate with 40 E. crus galli seeds and 40 $P$. ixocarpa seeds for each concentration of sample for five days (three days for germination and two days more for root and shoot growth). The number of seeds used for each experiment was selected for that show an appreciable change in $\mathrm{O}_{2}$ uptake that could be detected by the oxygraph (Yellow Spring Instrument) Model 5300. The test seeds were held in the dark at $28{ }^{\circ} \mathrm{C}$ in $9.0-\mathrm{cm}$ Petri dishes containing an $8.5-\mathrm{cm}$ sheet of Whatman No. 1 filter paper and $10.0 \mathrm{~mL}$ of test or control solution. Dishes were wrapped with Parafilm foil and incubated at $28{ }^{\circ} \mathrm{C}$ in the dark. The number of germinated seeds was determined according to the criterion of $1 \mathrm{~mm}$ extrusion of the radicle. Germination rates were counted at 72 and $120 \mathrm{~h}$ later for root and shoot growth measurements. 1 and $\mathbf{2}$ were initially dissolved in dimethyl sulfoxide (DMSO). The maximum final concentration of DMSO was less than $0.1 \%$ and the same DMSO concentration was used in the control solution [18].

\subsubsection{Plant Material for in Vivo Assays}

The seeds of $P$. ixocarpa and $L$. perenne, were sown in $12 \mathrm{~cm}$ diameter pots and were watered daily in the greenhouse at $27 \pm 2{ }^{\circ} \mathrm{C}$. After 15 and 18 days of emergence for P. ixocarpa and L. perenne, respectively, the plants were selected for similar size and were sprayed manually with the $\mathbf{1}$ and $\mathbf{2}$ at concentrations of 25,50 and $100 \mu \mathrm{g} / \mathrm{mL}$ (one stock of $10 \mathrm{mg} / \mathrm{mL}$ of each compound was prepared in DMSO). An aliquot of the stock solution was taken to obtain the desired concentration in an aqueous suspension containing $0.05 \% \mathrm{w} / \mathrm{v}$ of polyoxyethylenesorbitan monolaurate (Tween-20). The control samples were sprayed with distilled water containing the same amount of DMSO and Tween-20 [19].

\section{Conclusions}

Allelochemicals play a role in mediating interspecific interactions [20,21], and various plants enhance competitiveness and fitness [22,23]. $\beta$-caryophyllene (1), a well-known volatile sesquiterpene with allelopathic potential, has been reported to inhibit development of seedlings of various plant species $[24,25]$. In this work, for the first time from the $n$-hexane extract of aerial parts of $S$. salignus plants, were isolated $\beta$-caryophyllene and caryophyllene oxide. Compound 1 inhibited $42 \%$ the root elongation of Physalis ixocarpa seedling at $50 \mu \mathrm{g} / \mathrm{mL}$ and $53 \%$ at $150 \mu \mathrm{g} / \mathrm{mL}$ and it inhibited the root elongation of Echinochloa crus-galli to a lesser extent (30\% at $150 \mu \mathrm{g} / \mathrm{mL})$. On the other hand, compound 2 was inactive in both seedlings. Both compounds inhibited the dry biomass of Physalis ixocarpa plants, being $\beta$-caryophyllene the most active. The Chl $a$ fluorescence transient in vivo indicated that $100 \mu \mathrm{g} / \mathrm{mL}$ of $\beta$-caryophyllene presented a major effect on photosynthesis of P. ixocarpa plants $72 \mathrm{~h}$ after treatment, inhibiting PS II by transforming active reaction centers to "heat sinks" or the formation of silent reaction centers, and also induces chlorosis on treated leaves. 


\section{Acknowledgments}

We thank Facultad de Química (PAIP), UNAM and Dirección General de Asuntos del Personal Académico de la UNAM (DGAPA) for financial support (PAPIIT IN 211309, 205806 and IN 223411) and to Q. A. Acosta for spectroscopic assistance.

\section{References and Notes}

1. Romo de Vivar, A.; Pérez-Castorena, A.-L.; Arciniegas, A.; Villaseñor, J.L. Secondary metabolites from Mexican species of the Tribe senecioneae (Asteraceae). J. Mex. Chem. Soc. 2007, 51, 160-172.

2. Rodríguez, J.; Tello, H.; Quijano, L.; Calderón, J.; Gómez, F.; Romo, J.; Ríos, T. Flavonoids of Mexican plants, isolation and structure of santin and glycoferide. Rev. Latinoamer. Quim. 1974, 5, 41-53.

3. Bohlmann, F.; Zdero, C. Naturally occurring terpene derivatives, LVI. New furoeremophilanes from Mexican Senecio species. Chem. Ber. 1976, 109, 819-825.

4. Bohlmann, F.; Zdero, C.; Jakupovic, J.; Grenz, M.; Castro, V.; Kino, R.M.; Robinson, H.; Vincent, L.P.D. Further pyrrolizidine alkaloids and furoeremophilanes from Senecio species. Phytochemistry 1986, 25, 1151-1159.

5. Rzedowski, G.C.; de Rzedowski, J. Flora fanerogámica del valle de México. In Comisión nacional para el conocimiento y uso de la biodiversidad, 2nd ed.; Instituto de ecologia, A.C. y: Michoacán, Mexico, 2005; p. 1406.

6. Arrhenius, J.H.; Langenheim, L. Sesquiterpenes in leaf pocket resins of Capaifera species. Phytochemistry 1983, 22, 471-472.

7. Adams, R.P. Identification of Essential Oil Components by Gas Chromatography/Mass Spectroscopy; Allured Publishing Co.: Carol Stream, IL, USA, 1995; pp. 94-358.

8. Wang, R.-L.; Staehelin, C.; Peng, S.-L.; Wang, W.-T.; Xie, X.-M.; Lu, H.-N. Responses of Mikania micrantha, an invasive weed to elevated $\mathrm{CO}_{2}$ : Induction of $\beta$-caryophyllene synthase, changes in emission capability and allelopathic potential of $\beta$-caryophyllene. J. Chem. Ecol. 2010, 36, 1076-1082.

9. Perez-Vasquez, A.; Linares, E.; Bye, R.; Cerda-Garcia-Rojas, C.M.; Mata, R. Phytotoxic activity and conformational analysis of thymol analogs from Hofmeisteria schaffneri. Phytochemistry 2008, 69, 1339-1347.

10. Strasser, R.J.; Srivastava, A.; Govindjee. Polyphasic chlorophyll $a$ fluorescence transients in plants and cyanobacteria. Photochem. Photobiol. 1995, 61, 32-42.

11. Strasser, R.J.; Tsimilli-Michael, M.; Srivastava, A. Analysis of chlorophyll $a$ fluorescence transient. In Chlorophyll Fluorescence: A Signature of Photosynthesis; Papageorgiou, G.C., Govindjee, Eds.; Kluwer Academic Publishers: Dordrecht, The Netherlands, 2004; Chapter 12, pp. 321-362.

12. Aguilar, M.I.; Romero, M.G.; Chávez, M.I.; King-Díaz, B.; Lotina-Hennsen, B. Biflavonoids isolated from Selaginella lepidophylla inhibit photosynthesis in spinach chloroplasts. J. Agric. Food Chem. 2008, 56, 6994-7000. 
13. Mills, J.D.; Mitchell, P.; Schurrmann, P. Modulation of coupling ATPase activity in intact chloroplasts. FEBS Lett. 1980, 191, 144-148.

14. Torres-Romero, D.; King-Díaz, B.; Strasser, R.J.; Jiménez, I.A.; Lotina-Hennsen, B.; Bazzocchi, I.L. Friedelane triterpenes from Celastrus vulcanicola as photosynthetic inhibitors. J. Agric. Food Chem. 2010, 58, 10847-10854.

15. Strain, H.H.; Cope, B.T.; Svec, W.A. Analytical procedures for the isolation, identification, estimation and investigation of the chlorophylls. Meth. Enzymol. 1971, 23, 452-466.

16. Dilley, R.A. Ion transport $\left(\mathrm{H}^{+}, \mathrm{K}^{+}, \mathrm{Mg}^{2+}\right.$ exchange phenomena). Methods Enzymol. 1972, 24, 68-74.

17. Panda, D.; Rao, D.N.; Sharma, S.G.; Strasser, R.J.; Sarkar, R.K. Subemergence effects on rice genotypes during seedling stage: Probing of subemergence driven changes of photosystem II by chlorophyll $a$ fluorescence induction O-J-I-P transients. Photosynthetica 2006, 44, 69-75.

18. Céspedes, C.L.; Calderón, J.S.; Salazar, J.R.; Lotina-Hennsen, B.; Segura, R. Plant-growth inhibitory activity of cedrelanolide from Cedrela salvadorensis. J. Chem. Ecol. 2001, 27, 137-149.

19. González-Ibarra, M.; Farfán, N.; Trejo, C.; Uribe, S.; Lotina-Hennsen, B. Selective herbicide activity of 2,5-di(benzylamine)-p-benzoquinone against the monocot weed Echinochloa crus-galli. An in vivo analysis of photosynthesis and growth. J. Agric. Food Chem. 2005, 53, 3415-3420.

20. Dicke, M.; Sabelis, M.W.; Takabayashi, J.; Bruin, J.; Posthumus, M.A. Plant strategies of manipulating predator prey interactions through allelochemicals: Prospects for application in pest control. J. Chem. Ecol. 1990, 16, 3091-3118.

21. Inderjit; Duke, S.O. Ecophysiological aspects of allelopathy. Planta 2003, 217, 529-539.

22. Singh, H.P.; Batish, D.R.; Kohli, R.K. Allelopathic interactions and allelochemicals new possibilities for sustainable weed management. Crit. Rev. Plant Sci. 2003, 22, 239-311.

23. Kegge, W.; Pierik, R. Biogenic volatile organic compounds and plant competition. Trends Plant Sci. 2010, 15, 126-132.

24. Kil, B.S.; Han, D.M.; Lee, C.H.; Kim, Y.S.; Yun, K.Y.; Yoo, H.G. Allelopathic effects of Artemisia lavandulaefolia. Korean J. Ecol. 2000, 23, 149-155.

25. Wang, R.L.; Peng, S.L.; Zeng, R.S.; Ding, L.W.; Xu, Z.F. Cloning, expression and wounding induction of $\beta$-caryophyllene synthase gene from Mikania micrantha H. B. K. and allelopathic potential of $\beta$-caryophyllene. Allelopathy J. 2009, 24, 35-44.

Sample Availability: Not available.

(C) 2012 by the authors; licensee MDPI, Basel, Switzerland. This article is an open access article distributed under the terms and conditions of the Creative Commons Attribution license (http://creativecommons.org/licenses/by/3.0/). 